\title{
Lives in the balance: responsiveness of the corpus luteum to uterine and embryonic signals
}

\author{
J. L. Pate \\ Ohio State University/OARDC, 1680 Madison Ave, Wooster, OH 44691, USA
}

\begin{abstract}
This review focuses on factors that may affect the sensitivity of the corpus luteum to uterine prostaglandin $\mathrm{F}_{2 \alpha}\left(\mathrm{PGF}_{2 \alpha}\right)$ and embryonic signals. The heterogeneity of the types of cell that are present within the corpus luteum results in complex interactions that ensure complete luteal regression in response to $\mathrm{PGF}_{2 \alpha}$. There is not likely to be a single factor that determines responsiveness. The sensitivity of the corpus luteum depends on the proper balance of a variety of factors that are involved in mediating the effects of $\mathrm{PGF}_{2 \alpha}$. This balance is achieved as the early corpus luteum undergoes development, but may also be altered by embryonic factors to rescue the corpus luteum during early pregnancy.
\end{abstract}

\section{Introduction}

Communication between the uterus and ovary is essential for normal cyclicity and the maintenance of pregnancy in ruminants. Luteal lifespan is prolonged in hysterectomized animals (Wiltbank and Casida, 1956) because of the lack of prostaglandin $F_{2 \alpha}\left(P\left(F_{2 \alpha}\right)\right.$, and ovarian steroids regulate the timing and concentrations of uterine $\mathrm{PGF}_{2 \alpha}$ release. Exogenous $\mathrm{PGF}_{2 \alpha}$ has been used for many years to regulate the oestrous cycles of ruminant species, but the developing corpus luteum is refractory to the luteolytic actions of $\mathrm{PGF}_{2 \alpha}$ (Louis et al. 1973). Progesterone synthesis by the corpus luteum is essential for maintenance of pregnancy, and the presence of a healthy embryo is required to rescue the corpus luteum from regression. Clearly, the main role of embryonic interferon $\tau$ (IFN $-\tau$ ) in maternal recognition of pregnancy is to decrease the amount of $\mathrm{PGF}_{2 \alpha}$ released by the uterus, thus preventing luteal regression. However, alterations in luteal function during maternal recognition of pregnancy also render the corpus luteum less sensitive to the luteolytic effects of $\mathrm{PGF}_{2 \alpha}$.

The heterogeneous nature of the corpus luteum indicates that there is a complex interaction of different types of cell and paracrine mediators that regulate the sensitivity of the corpus luteum to extraovarian signals. There is increasing evidence that the non-steroidogenic cells may affect the steroidogenic capacity of the corpus luteum and are directly involved in both the formation and demise of the tissue. The rapid angiogenesis that occurs during luteinization and the extensive vascularity within the mature corpus luteum has led a number of investigators to consider the functional significance of capillary endothelial cells to steroidogenesis. Growth factors, such as vascular endothelial growth factor (VEGF), are important 
in the development of the capillary network that will sustain the corpus luteum (Redmer et al., 1996; Berisha et al., 2000) and proliferation of capillary pericytes may be a key factor in achieving full luteal maturation (Redmer et al., 2001). The interactions of the various types of cell and paracrine factors within the corpus luteum, with regard to how these may alter the sensitivity of the corpus luteum to uterine factors, such as PGF P $_{2 \alpha}$ or embryonic signals, is the subject of this review. Owing to the limited length of the review and the symposium for which it is prepared, the focus is on ruminants, and previous review articles are cited wherever possible.

\section{Local mediators of prostaglandin action in mature corpus luteum}

Prostaglandin $\mathrm{F}_{2 \alpha}$ acts on steroidogenic cells to bring about a rapid decrease in progesterone production. Activation of the phospholipase $\mathrm{C}$-protein kinase $\mathrm{C}$ pathway by $\mathrm{PGF}_{2 \alpha}$ results in an increase in intracellular calcium, a decrease in mRNAs for steroidogenic enzymes and steroidogenic acute regulatory protein (StAR), and inhibition of cholesterol transport through the mitochondrial membrane. The actions of $\mathrm{PGF}_{2 \alpha}$ on steroidogenic cells to inhibit progesterone production have been reviewed elsewhere (Pate and Townson, 1994; Niswender et al., 2000).

The luteolytic effects of $\mathrm{PGF}_{2 \alpha}$ may also be advanced by the non-steroidogenic cells within the corpus luteum. Prostaglandin $\mathrm{F}_{2 \alpha}$ is a more effective inhibitor of progesterone synthesis in the presence of endothelial cells (Girsh et al., 1995), indicating that endothelial cells mediate the antisteroidogenic effects of $P G F_{2 \alpha}$. Prostaglandin $F_{2 \alpha}$ causes a rapid increase in endothelin 1 (ET-1) mRNA in the mature corpus luteum, and ET-1 acts on luteal cells to decrease progesterone production in vitro and in vivo (Girsh et al., 1996; Miyamoto et al., 1997; Ohtani et al., 1998; Hinckley and Milvae, 2001). The most convincing evidence that ET-1 may serve as a mediator of $\mathrm{PGF}_{2 \alpha}$ action in the corpus luteum was reported by Hinckley and Milvae (2001) who demonstrated that administration of ET-1 to ewes in the presence of a subluteolytic dose of $\mathrm{PGF}_{2 \alpha}$ resulted in luteolysis, and inhibition of the ET-1 receptor, ETA, prevented $\mathrm{PGF}_{2 \alpha}$-induced luteolysis. The morphology of endothelial cells changes in response to $\mathrm{PGF}_{2 \alpha}$ before any apparent change in steroidogenic cells (Sawyer et al., 1990), and Gaytan et al., (2002) demonstrated that endothelial cells in the rat corpus luteum undergo apoptosis followed by ischaemic necrosis of the luteal cells. Sufficient development of the microvasculature with adequate numbers of endothelial cells may promote the sensitivity of the corpus luteum to $\mathrm{PGF}_{2 \alpha}$.

Immune cells are intricately involved in the progression of luteolysis once it has been initiated by $\mathrm{PGF}_{2 \alpha}$, and they may also contribute to both the continued decrease in progesterone production as well as the structural demise of the tissue (for reviews, see Pate and Townson, 1994; Pate, 1995; Pate and Keyes, 2001). In cows, lymphocytes are present in the fully functional corpus luteum and increase at the time of luteal regression (Lobel and Levy, 1968; Penny et al., 1999; Townson et al., 2002). The increase in immune cells appears to be due to migration of these cells into the tissue as well as proliferation, particularly of macrophages, within the tissue (Bauer et al., 2001). The expression of monocyte chemoattractant protein 1 (MCP-1) in the corpus luteum is likely to be responsible for the recruitment of macrophages into the tissue (Bowen et al., 1996; Townson et al., 1996; Penny et al., 1998). Cytokines, such as tumour necrosis factor $\alpha$ (TNF- $\alpha$ ) and interferon $\gamma$ (IFN- $\gamma$ ), produced by immune cells within the corpus luteum may contribute to the inhibition of steroidogenesis and cell death (Fairchild and Pate, 1991; Benyo and Pate, 1992; Petroff et al., 2001). 


\section{Acquisition of luteolytic capacity}

The transition from a $\mathrm{PGF}_{2 \alpha}$ non-responsive, or insensitive state, to a $\mathrm{PGF}_{2 \alpha}$-responsive state has been termed the 'acquisition of luteolytic capacity' by Diaz et al. (2000). Initial suggestions that the developing corpus luteum was insensitive to $\mathrm{PGF}_{2 \alpha}$ because it lacked $\mathrm{PGF}_{2 \alpha}$ receptors (FP) were found to be incorrect. Both Rao et al. (1979) and Wiltbank et al. (1995) demonstrated that there are similar numbers and affinity of PGF $_{2 \alpha}$ receptors in early, non-responsive corpora lutea as in mature corpora lutea of cattle. This finding is unlike that in pigs, in which a significant increase in FP receptors occurs at about the time that the corpus luteum becomes responsive to $\mathrm{PGF}_{2 \alpha}$ (Gadsby et al., 1990). When nonresponsive (day 4) or responsive (day 11) bovine corpora lutea were treated with PGF $_{2 \alpha}$ in vivo, the concentration of luteal ascorbate and mRNAs for $3 \beta$-hydroxysteroid dehydrogenase $(3 \beta-H S D)$ and FP receptor were decreased, and insulin-like growth factor binding protein 1 (IGFBP-1) was increased in both day 4 and day 11 corpora lutea, indicating that the day 4 corpora lutea are not completely unresponsive to $\mathrm{PGF}_{2 \alpha}$ actions (Tsai and Wiltbank, 1998; Sayre et al., 2000). However, day 11 corpora lutea responded to $\mathrm{PGF}_{2 \alpha}$ with an increase in steady state concentrations of mRNA for prostaglandin G/H synthase-2 (PGHS-2, also known as cyclooxygenase 2), whereas a decrease in PGHS-2 was observed in day 4 corpora lutea (Tsai and Wiltbank, 1998). This finding led the authors to suggest that the ability of the corpus luteum to establish a positive autocrine feedback loop of endogenous prostaglandin synthesis is a key component for the acquisition of luteolytic capacity. This suggestion supports the findings of Milvae (1986), in which it was proposed that stimulation of luteal prostaglandin synthesis is a critical factor in luteal regression, and extends this concept to help explain why the early (developing) corpus luteum is not induced to regress by exogenous $\mathrm{PGF}_{2 \alpha}$. In fact, multiple $\mathrm{PGF}_{2 \alpha}$ injections increase luteal PGHS-2 concentrations and also induce luteolysis in the day 4 corpus luteum (Beal et al., 1980; Sayre et al., 2000). The importance of luteal prostaglandins to $\mathrm{PGF}_{2 \alpha}$-induced luteolysis is further exemplified by the finding that the activity of prostaglandin dehydrogenase (PGDH), which metabolizes $\mathrm{PGF}_{2 \alpha}$ to its inactive metabolite, PGFM, is greater in the early, non-responsive corpora lutea than in the mid-cycle (fully functional), responsive corpora lutea (Silva et al., 2000).

If endothelial cells and ET-1 secretion are mediators of $\mathrm{PGF}_{2 \alpha}$-induced luteolysis, then it is reasonable to postulate that the underdeveloped microvasculature characteristic of the early corpus luteum is inadequate to mediate the luteolytic signal. In fact, this hypothesis was first proposed by Levy et al. (2000), who demonstrated that mRNAs for ET-1 and ETA were increased by $\mathrm{PGF}_{2 \alpha}$ in the mid-cycle corpus luteum, but remained unchanged in the day 4 corpus luteum, despite other effects of $\mathrm{PGF}_{2 \alpha}$ at that time. The difference in the ET-1 response to $\mathrm{PGF}_{2 \alpha}$ in early and mid-cycle corpora lutea was further corroborated by Wright et al. (2001). These investigators also measured endothelin converting enzyme 1 (ECE-1) and found that it was decreased as a result of $\mathrm{PGF}_{2 \alpha}$ in mid-cycle, but not in early, corpora lutea. In addition to its antisteroidogenic effects, ET-1 is a potent vasoconstrictor. Although vasoconstriction appears to occur after the decline in progesterone, this could be another action of ET-1 to continue the progression of luteolysis (for a review, see Niswender et al., 2000). Acosta et al. (2002) used pulsed Doppler ultrasonography to evaluate blood flow in day 4 and day 10 bovine corpora lutea. In the mid-cycle corpus luteum, PGF $_{2 \alpha}$ treatment caused an acute increase followed by a gradual decrease in blood flow, whereas no change in blood flow was associated with $\mathrm{PGF}_{2 \alpha}$ treatment on day 4 of the oestrous cycle. These results lend further support to the concept that endothelial cells and the luteal microvasculature are not sufficiently developed in the early corpus luteum to allow for a complete luteolytic response to $\mathrm{PGF}_{2 \alpha}$. 

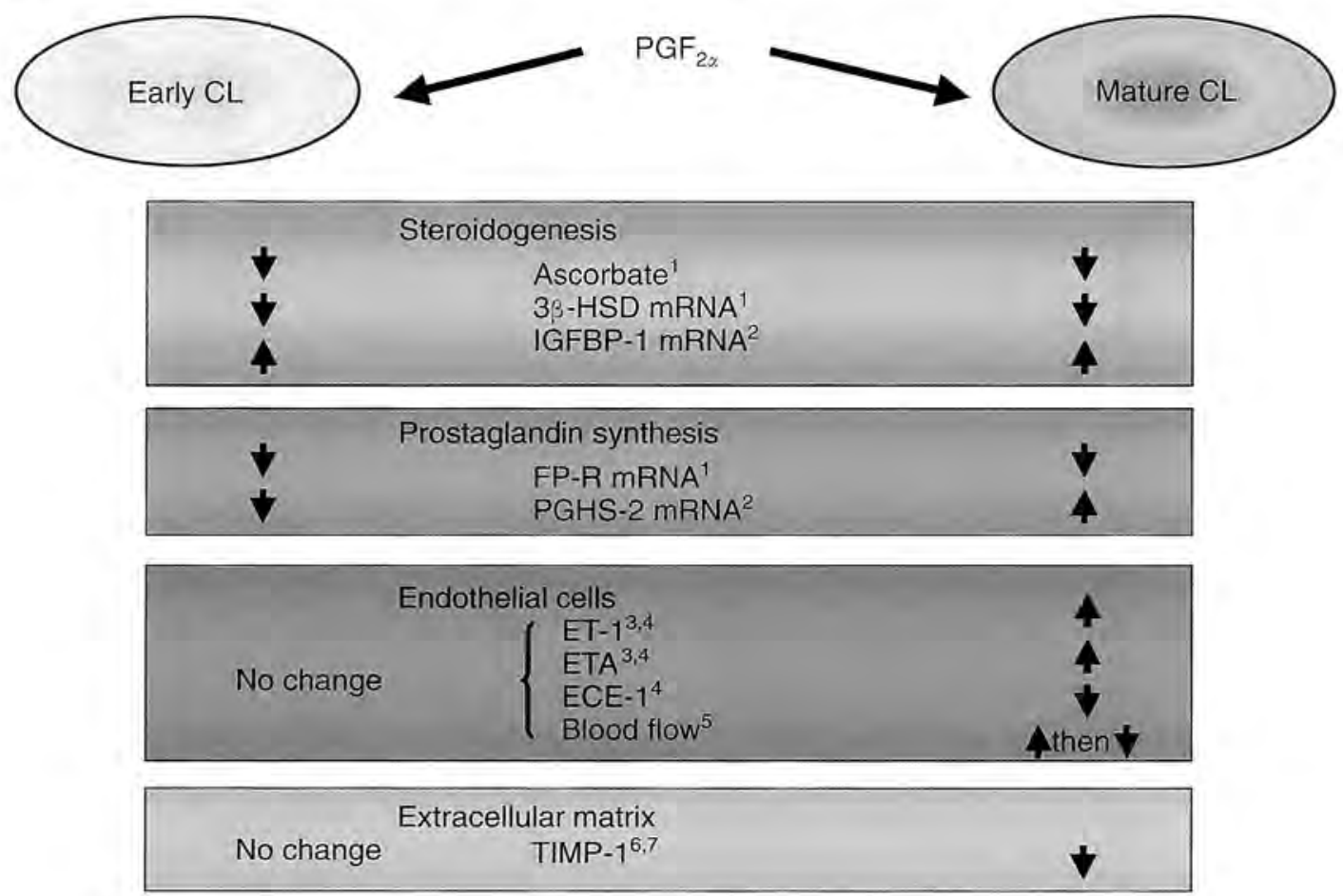

No change ${ }_{\mathrm{MCP}-1^{8}}^{\text {Cytokines }}$

Fig. 1. Effects of prostaglandin $F_{2 \alpha}\left(P_{F_{2 \alpha}}\right.$ ) on early (non-responsive) and mid-cycle mature (responsive) corpora lutea (CL). Differences in prostaglandin G/H synthase 2 (PGHS-2) and the inability to effect changes in endothelial cells, extracellular matrix remodelling components and cytokines in the early corpus luteum may prevent the luteolytic effects of $\mathrm{PGF}_{2 \alpha}$ from being fully manifested. $3 \beta$-hydroxysteroid dehydrogenase ( $3 \beta-\mathrm{HSD}$ ); insulin-like growth factor binding protein 1 (IGFBP-1); $\mathrm{PGF}_{2 \alpha}$ receptor (FP); endothelin-1 (ET-1); ET-1 receptor (ETA); endothelin converting enzyme 1 (ECE-1); tissue inhibitor of metalloproteinase 1 (TIMP-1); monocyte chemoattractant factor 1 (MCP-1). 'Tsai and Wiltbank (1998); ${ }^{2}$ Sayre et al. (2000); ${ }^{3}$ Levy etal. (2000); ${ }^{4}$ Wright etal. (2001); ${ }^{5}$ Acosta etal. (2002); ${ }^{6}$ Ricke et al. (2002); ${ }^{7}$ Towle et al. (2002); and ${ }^{8}$ Tsai et al. (1997).

The ability of $\mathrm{PGF}_{2 \alpha}$ to promote reorganization of the extracellular matrix and tissue degradation may also be a component of the acquisition of luteolytic capacity. When cows or ewes are treated with $\mathrm{PGF}_{2 \alpha}$ during mid-cycle, there is a rapid and sustained depletion of luteal tissue inhibitor of metalloproteinase 1 (TIMP-1) and an increase of luteal matrix metalloproteinase 2 (MMP-2; Ricke et al., 2002; Towle et al., 2002). However, there is no effect of $\mathrm{PGF}_{2 \alpha}$ on luteal concentrations of TIMP when administered on day 3 of the oestrous cycle (Ricke et al., 2002). A summary of the responses to PGF $_{2 \alpha}$ that occur in early and mid-cycle corpora lutea is presented (Fig. 1).

Other types of cell in the corpus luteum that may influence luteolytic capacity are the immune cells. There are fewer T lymphocytes, monocytes and macrophages in the corpus luteum early in the oestrous cycle compared with later in the oestrous cycle, and the amount of immunoreactive MCP-1 and MCP-1 mRNA in the bovine corpus luteum parallels the number of immune cells present (Townson et al., 2002). Tsai et al. (1997) observed that MCP-1 mRNA was increased by a luteolytic injection of $\mathrm{PGF}_{2 \alpha}$ in mid-cycle corpora lutea, but there was 
no MCP-1 response in early corpora lutea. Thus, the inability of the early corpus luteum to respond to $\mathrm{PGF}_{2 \alpha}$ with an increase in MCP-1, and an insufficient number of immune cells within the tissue may well be an important factor in the luteolytic effect of PGF $_{2 \alpha}$ not being fully manifested.

If immune cells are important for the acquisition of luteolytic capacity, it might be expected that cytokine concentrations would be low, or absent, in the early corpus luteum but high in the mid-cycle corpus luteum. Very little has been done to evaluate cytokine concentrations in early compared with mature corpora lutea in ruminants, and the results are not always consistent. This is due, in part, to the lack of reagents for analysis of the bovine or ovine proteins. One of the most studied cytokines in the corpus luteum is $T N F-\alpha$. The mRNA for TNF $\alpha$ is present throughout the lifespan of the bovine corpus luteum (Petroff et al., 1999; Sakumoto et al., 2000); therefore, expression of this gene may not be limiting in terms of luteolytic capacity. However, the TNF- $\alpha$ protein is not detected until the corpus luteum is mature (Sakumoto et al., 2000) or until after luteal regression has been initiated by $\mathrm{PGF}_{2 \alpha}$ (Ji et al., 1991; Shaw and Britt, 1995). The effect of PGF $F_{2 \alpha}$ on TNF- $\alpha$ synthesis in early and mature corpora lutea has not yet been reported, and is the subject of current investigation in our laboratory. There have been conflicting reports on the presence of the type I TNF receptor (TNF-RI) in luteal tissue. Friedman et al. (2000) reported no difference in the mRNA for TNF-RI in luteal tissue of various ages; Sakumoto et al. (2000) found the mRNA content to be high early in the oestrous cycle, whereas M. G. Petroff and J. L. Pate (unpublished) observed a lower content in day 5 compared with mid-cycle corpora lutea. Clearly this issue is not resolved, and the relevance of the TNF-TNF-RI system to the acquisition of luteolytic capacity will depend on knowledge of the proteins, not just of the mRNAs. As the pro-inflammatory cytokines, such as TNF- $\alpha$ and IFN- $\gamma$, are potent stimulators of luteal prostaglandin synthesis (Fairchild and Pate, 1991; Benyo and Pate, 1992; Townson and Pate, 1996), it is possible that lack of cytokine production in response to $\mathrm{PGF}_{2 \alpha}$ in the early corpus luteum contributes to its inability to synthesize endogenous prostaglandins and hence its lack of luteolytic capacity.

Another rather novel cytokine, macrophage migration inhibitory factor (MIF), was examined in bovine corpora lutea throughout the oestrous cycle. It was expected that MIF would be absent during luteal development and increase at the time of luteolysis. Surprisingly, the opposite was true. MIF MRNA was consistently high in day 5 corpora lutea, and expression was lower in mid-cycle or day 18 corpora lutea. Immunohistochemistry revealed that MIF was found in the steroidogenic cells, primarily the large luteal cells (Bove et al., 2000). It was hypothesized that MIF is involved in differentiation events during luteinization, and there is now a question as to whether higher concentrations of MIF render the corpus luteum less sensitive to $\mathrm{PGF}_{2 \alpha}$.

Recent work in our laboratory has focused on the components of the intracellular peptide processing system for presentation of peptides by major histocompatibility complex (MHC) molecules, and the temporal expression of these molecules in the bovine corpus luteum. Processing of peptides presented by MHC class I molecules takes place within the proteosome, and exposure to IFN- $\gamma$ induces replacement of constitutive proteosome subunits with the IFN- $y$-inducible subunits, low molecular weight protein 2 (LMP-2), LMP7 and LMP10. No significant differences were observed in steady state concentrations of LMP7 MRNA, but the LMP10 mRNA content was lower in the day 5 corpora lutea in comparison with corpora lutea at day 11 or day 18 of the oestrous cycle (Cannon and Pate, 2000a). MHC class II molecules present peptides that are processed by the invariant chain and the DM protein. Although no differences were noted in the steady state concentrations of the invariant chain in the bovine corpus luteum throughout the oestrous cycle, both the DM $\alpha$ and DM $\beta$ subunits increased from 
Early CL

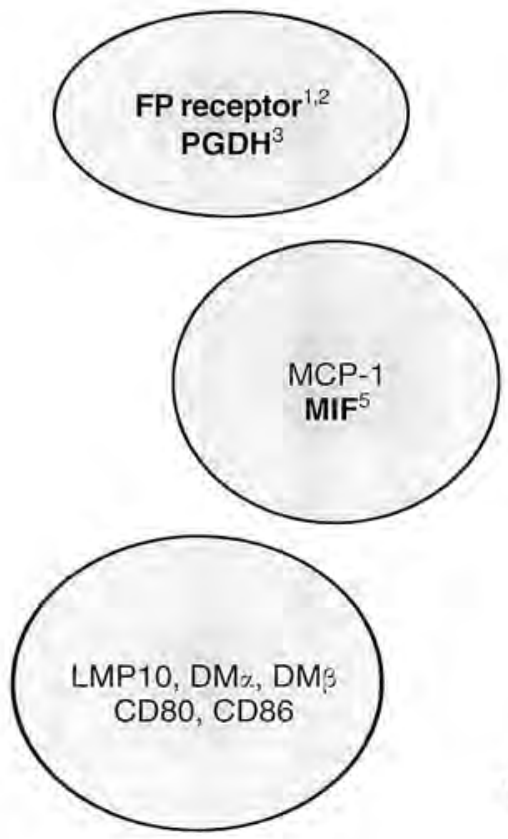

Mid-cycle CL

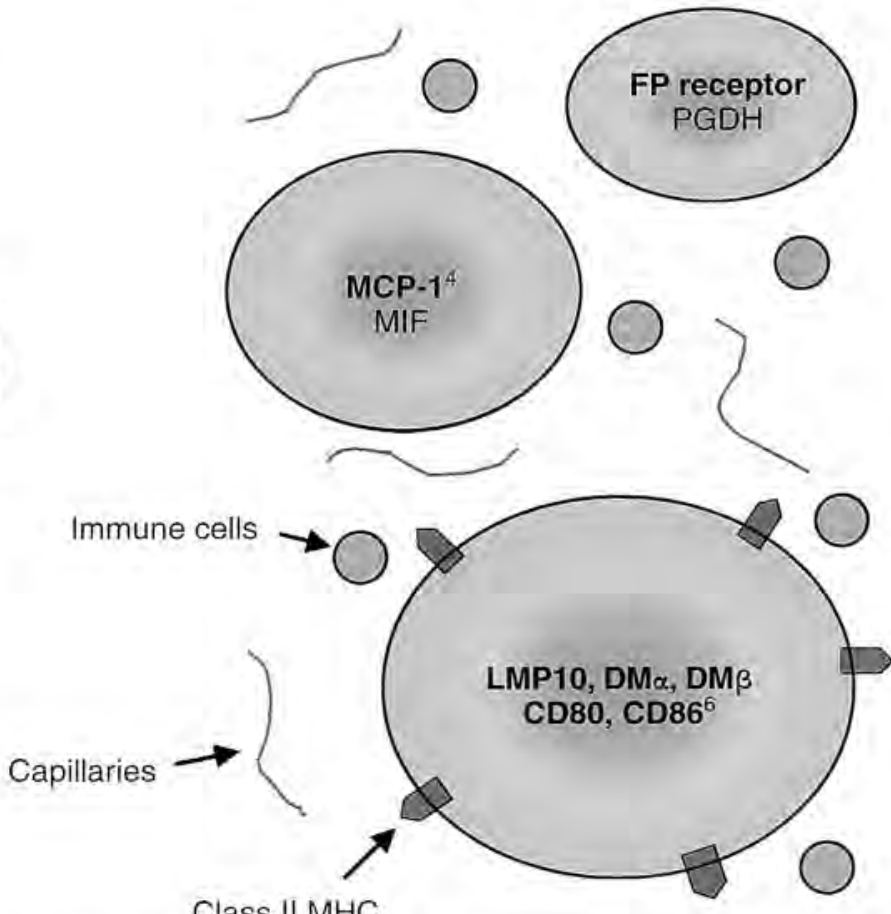

Class II MHC

Fig. 2. Components of early prostaglandin $\mathrm{F}_{2 \alpha}\left(\mathrm{PGF}_{2 \alpha}\right)$ (non-responsive) and mid-cycle PGF $F_{2 \alpha}$ (responsive) corpora lutea that may affect acquisition of luteolytic capacity. Bold letters indicate a relatively higher concentration compared with those that are not depicted in bold letters. In addition to relative changes in concentrations of the various components, the mid-cycle corpus luteum contains immune cells, major histocompatibility complex (MHC) class II molecules, and a more developed capillary network. Prostaglandin dehydrogenase (PGDH), monocyte chemoattractant factor 1 (MCP-1), $\mathrm{PGF}_{2 \alpha}$ receptor (FP), macrophage migration inhibitory factor (MIF), LMP10, DMo and DM $\beta$ are antigen processing proteins, and CD80 and CD86 are co-stimulatory molecules. ' Rao et al. (1979); ${ }^{2}$ Wiltbank et al. (1995); ${ }^{3}$ Silva et al. (2000); ${ }^{4}$ Townson et al. (2002); ${ }^{3}$ Bove et al. (2000); and ${ }^{6}$ Cannon and Pate (2000a, b; 2001).

day 5 to day 10 of the oestrous cycle (Cannon and Pate, 2000b). These results are similar to the pattern of MHC class II expression within the corpus luteum that was reported earlier (Benyo et al., 1991), in that MHC class II molecules are absent in the early corpus luteum, but are found in the mid-cycle corpus luteum. Furthermore, fewer of the co-stimulatory molecules that are necessary for MHC-mediated activation of T lymphocytes, CD80 and CD86, were found in early corpora lutea than in mid-cycle corpora lutea (Cannon and Pate, 2001). The addition of CD80 or CD86 antibodies to luteal cell-T cell co-cultures inhibited luteal cell-induced T-cell proliferation, indicating that these costimulatory molecules are necessary for activation of T cells within the corpus luteum (Cannon and Pate, 2001). Lower expression of peptide processing components and co-stimulatory molecules in the early corpus luteum may mean that T-cell activation cannot occur at this stage, and may contribute to the refractory nature of the early corpus luteum to $\mathrm{PGF}_{2 \alpha}$. In the mid-cycle corpus luteum, which is fully responsive to $\mathrm{PGF}_{2 \alpha}$, the components necessary for activation of the immune response are in place. Experiments are currently underway to determine whether the increase in expression of these components is correlated with the timing of acquisition of 
luteolytic capacity. Components that are differentially expressed in early and mid-cycle corpora lutea that may be critical for the acquisition of luteolytic capacity are summarized (Fig. 2).

\section{Resistance of the corpus luteum to $\mathrm{PGF}_{2 \alpha}$ during maternal recognition of pregnancy}

There is little question that embryonic factors, particularly IFN- $\tau$, act on the endometrium to alter $\mathrm{PGF}_{2 \alpha}$ secretion during maternal recognition of pregnancy (for a review, see Thatcher, this supplement). In addition to the changes that occur in the endometrial secretion of $\mathrm{PGF}_{2 \alpha}$ during early pregnancy, it has been suggested that embryonic factors also decrease the sensitivity of the corpus luteum to $\mathrm{PGF}_{2 \alpha}$ (Pratt et al, 1977).

Silvia and Niswender (1984) demonstrated that the corpus luteum of pregnancy (in sheep) is less sensitive to $\mathrm{PGF}_{2 \alpha}$ than the corpus luteum of the ovarian cycle, and the number of embryos may be inversely correlated with the sensitivity of the corpus luteum to PGF $2 \alpha$. Furthermore, in vitro secretion of progesterone by luteal tissue was greater when corpora lutea came from ewes with healthy embryos compared with ewes with abnormal embryos, and both of these were greater than when the corpora lutea came from ewes with no embryos (Abecia et al, 2001). In addition to increasing luteal progesterone production, treatment of luteal cells with conceptus secretory proteins reversed the inhibitory effects of $\mathrm{PGF}_{2 \alpha}$ on progesterone production (Wiltbank et al., 1992). Therefore, the steroidogenic capacity of the corpus luteum is enhanced, and its sensitivity to $\mathrm{PGF}_{2 \alpha}$ is reduced, by factors produced by healthy embryos. The ability of immune cells to promote luteolysis may also be impaired during maternal recognition of pregnancy, because there are fewer immune cells and class II $\mathrm{MHC}$ molecules within the corpus luteum during early pregnancy than late in the oestrous cycle (Lobel and Levy, 1968; Benyo et al., 1991). Furthermore, IFN- $\alpha$, which has properties very similar to IFN- $\tau$, protects luteal cells from the cytotoxic effects of TNF- $\alpha$ and IFN- $\gamma$, and decreases the ability of these cytokines to stimulate luteal prostaglandin production (Petroff et al., 2001). This result raises the very intriguing question of what changes occur within the corpus luteum to make it less responsive to $\mathrm{PGF}_{2 \alpha}$ and if these changes rely on mechanisms similar to those found in the early corpus luteum that is not yet responsive to $\mathrm{PGF}_{2 \alpha}$.

Recently, a new concept has emerged that the lack of sensitivity of the corpus luteum during maternal recognition of pregnancy is due to the ability of the corpus luteum to convert $\mathrm{PGF}_{2 \alpha}$ to its inactive metabolite, PGFM (Silva et al., 2000). These workers clearly showed that day 13 corpora lutea from pregnant ewes had greater concentrations and activity of PGDH (the enzyme that metabolizes PGF $\mathrm{PG}_{2 \alpha}$ to PGFM) than day 13 corpora lutea from cyclic ewes. The greater concentration of $\mathrm{PGDH}$ was similar to that at day 4 , as mentioned above. Therefore, the ability to metabolize $\mathrm{PGF}_{2 \alpha}$ may be a common element that renders the corpus luteum less sensitive to the luteolytic effects of $\mathrm{PGF}_{2 \alpha}$.

\section{What maintains the corpus luteum after IFN- $\tau$ declines?}

The resistance to $\mathrm{PGF}_{2 \alpha}$ that is manifested during maternal recognition of pregnancy is lost by day 19 of pregnancy in sheep (Silvia and Niswender, 1986). Little is known about maintenance of the corpus luteum after maternal recognition of pregnancy. When IFN- $\tau$ decreases, are there other factors produced by the embryo or placenta that maintain the corpus luteum? Does failure of the embryo to produce adequate luteotrophic signals, or failure of the corpus 
luteum to respond to luteotrophins, contribute to late embryonic or fetal loss in ruminants? Although some of these losses are not likely to be due to inadequate luteal function, there is some evidence that late embryos or fetuses can be rescued by induction of a new corpus luteum (for a review, see Inskeep, 2002), implying that some fetal losses are a result of luteal insufficiency.

If the resistance to $\mathrm{PGF}_{2 \alpha}$ is lost shortly after the period of maternal recognition of pregnancy, additional mechanisms must account for continued luteal function. In ewes and cows, the luteotrophin may shift from $\mathrm{LH}$ during the oestrous cycle to $\mathrm{PGE}_{2}$ during pregnancy (Weems et al., 1998; Kim et al., 2001); thus, an inability to shift from LH to PGE 2 support could result in fetal loss. In rats, placental factors may contribute to luteal maintenance and stimulation of progesterone production by stimulating increases of $\mathrm{Cu}, \mathrm{Zn}$-superoxide dismutase (SOD) and Mn-SOD within the corpus luteum (Takiguchi el al., 2000), thus conferring resistance to reactive oxygen species that contribute to the luteolytic actions of PGF $F_{2 \alpha}$. Additional information obtained from the rat model has been used to indicate that the sensitivity of the corpus luteum to luteolytic agents is dependent on the degree of differentiation of the luteal cells. The corpus luteum of pregnancy is less sensitive to the luteolytic effects of prolactin than the corpus luteum of the ovarian cycle (Gaytan et al., 2001). These authors postulated that the responsiveness of the corpus luteum to the luteolytic effects of prolactin is dependent on the degree of differentiation of the luteal cells, that is, the more differentiated cells in pregnancy were less sensitive than the less differentiated cells during the oestrous cycle. Perhaps having survived luteolysis during maternal recognition of pregnancy, the corpus luteum further differentiates and is less sensitive to additional luteolytic signals. This contention would not be supported by the finding that luteal insensitivity to PGF $2 \alpha$ was lost by day 19 of pregnancy (Silvia and Niswender, 1986), unless the factor that causes luteolysis after the period of maternal recognition of pregnancy is something other than $\mathrm{PGF}_{2 \alpha}$. The question remains whether an additional uterine or embryonic signal is necessary for maintenance of the corpus luteum after the period of maternal recognition of pregnancy, or if the signal during maternal recognition of pregnancy promotes differentiative events within the corpus luteum that, if complete, protect the corpus luteum from subsequent luteolytic insults.

\section{Conclusions}

Much has been done to understand the mechanisms by which $\mathrm{PGF}_{2 a}$ causes luteolysis in ruminants. As this knowledge has unfolded, it has provided insight into the components that affect the sensitivity of the corpus luteum to $\mathrm{PGF}_{2 \alpha}$. Recent studies have focused on the acquisition of luteolytic capacity as the corpus luteum develops, and it is likely that a continuum of events occurs that culminates in responsiveness to the luteolytic effects of PGF $F_{2 \alpha}$. These events include changes in expression of genes important for luteal prostaglandin synthesis and metabolism, development of the luteal microvasculature and extracellular matrix, and an influx of immune cells and cytokine expression within the tissue. The sensitivity of the corpus luteum to $\mathrm{PGF}_{2 \alpha}$ is again reduced during maternal recognition of pregnancy. It remains to be determined whether these mechanisms are similar to those that decrease responsiveness during luteal development, and whether they are sufficient to prevent the fetal loss that is observed in ruminants. The ability of the corpus luteum to survive luteolytic insults is likely to depend on the correct balance of a variety of factors and the cells that produce them. Achieving this balance at the proper time may be the key to luteal survival or luteal regression. 


\section{References}

Abecia JA, Forcada F and Zuniga O (2001) Differences in reproductive performance, embryo development, interferon-tau secretion by the conceptus and luteal function in ewe lambs synchronized in oestrus before or after the spontaneous onset of luteal activity preceding puberty Reproduction in Domestic Animals $3673-77$

Acosta TJ, Yoshizawa $N$, Ohtani $M$ and Miyamoto $A$ (2002) Local changes in blood flow within the earlyand mid-cycle corpus luteum after prostaglandin $F_{2 \alpha}$ injection in the cow Biology of Reproduction 66 651-658

Bauer M, Reibiger I and Spanel-Borowski K (2001) Leucocyte proliferation in the bovine corpus luteum Reproduction 121 297-305

Beal WE, Milvae RA and Hansel W (1980) Oestrous cycle length and plasma progesterone concentrations following administration of prostaglandin $F_{2 \alpha}$ early in the bovine oestrous cycle Journal of Reproduction and Fertility 59 393-396

Benyo DF and Pate JL (1992) Tumor necrosis factor- $\alpha$ alters bovine luteal cell synthetic capacity and viability Endocrinology $\mathbf{1 3 0} 854-860$

Benyo DF, Haibel GK, Laufman HB and Pate JL (1991) Expression of major histocompatibility complex antigens on the bovine corpus luteum during the oestrous cycle, luteolysis and early pregnancy Biology of Reproduction $45229-234$

Berisha B, Schams D, Kosmann M, Amselgruber W and Einspanier R (2000) Expression and tissue concentration of vascular endothelial growth factor, its receptors, and localization in the bovine corpus luteum during the oestrous cycle and pregnancy Biology of Reproduction 631106-1114

Bove SE, Petroff MG, Nishibori M and Pate JL (2000) Macrophage migration inhibitory factor in the bovine corpus luteum: characterization of steady-state messenger ribonucleic acid and immunohistochemical localization Biology of Reproduction 62 879-885

Bowen JM, Keyes PL, Warren JS and Townson DH (1996) Prolactin-induced regression of the rat corpus luteum: expression of monocyte chemoattractant protein-1 and invasion of macrophages Biology of Reproduction 54 1120-1127 Erratum (1996) 55224

Cannon MJ and Pate IL (2000a) Expression of LMP7 and LMP10 proteasome subunits in bovine luteal tissue throughout the oestrous cycle and during $\mathrm{PGF}_{2 \alpha}$-induced luteal regression American lournal of Reproductive Immunology 43336

Cannon MJ and Pate JL (2000b) Presence and steadystate amounts of mRNA encoding class II MHC anti gen processing proteins in bovine luteal tissue during the oestrous cycle and PGF $2 \alpha$-induced luteal regression Biology of Reproduction 62144 (Abstract)

Cannon MJ and Pate JL (2001) Presence and steadystate amounts of mRNA encoding costimulatory molecules CD80 and CD86 in bovine luteal tissue during the oestrous cycle and $\mathrm{PGF}_{2 \alpha}$-induced luteal regression Biology of Reproduction $\mathbf{6 4 2 8 7}$

Diaz FJ, Crenshaw TD and Wiltbank MC (2000) Prostaglandin $\mathrm{F}_{2 \alpha}$ induces distinct physiological responses in porcine corpora lutea after acquisition of luteolytic capacity Biology of Reproduction 63 1504-1512

Fairchild DL and Pafe FL (1991) Modulation of bovine luteal cell synthetic capacity by interferon-gamma Biology of Reproduction 44 357-363

Friedman A, Weiss S, Levy N and Meidan R (2000) Role of tumor necrosis factor- $\alpha$ and its type 1 receptor in luteal regression: induction of programmed cell death in bovine corpus luteum-derived endothelial cells Biology of Reproduction 63 1905-1912

Gadsby JE, Balapure AK, Britt JH and Fitz TA (1990) Prostaglandin $\mathrm{F}_{2 \alpha}$ receptors on enzyme-dissociated pig luteal cells throughout the oestrous cycle Endocrinology 126787-795

Gaytan F, Bellido C, Morales C and Sanchez-Criado JE (2001) Luteolytic effect of prolactin is dependent on the degree of differentiation of luteal cells in the rat Biology of Reproduction 65 433-441

Gaytan F, Morales C, Bellido C and Sanchez-Criado JE (2002) Selective apoptosis of luteal endothelial cells in dexamethasone-treated rats leads to ischemic necrosis of luteal tissue Biology of Reproduction $\mathbf{6 6}$ $232-240$

Girsh E, Greber Y and Meidan R (1995) Luteotrophic and luteolytic interactions between bovine small and large luteal-like cells and endothelial cells Biology of Reproduction 59 954-962

Girsh E, Milvae RA, Wang W and Meidan R (1996) Effect of endothelin-1 on bovine luteal cell function: role in prostaglandin $\mathrm{F}_{2 \alpha}$-induced antisteroidogenic action Endocrinology 137 1306-1312

Hinckley ST and Milvae RA (2001) Endothelin-1 mediates prostaglandin $\mathrm{F}_{2 \alpha}$-induced luteal regression in the ewe Biology of Reproduction 641619 1623

Inskeep EK (2002) Factors that affect embryonic survival in the cow: application of technology to improve calf crop. In Factors Affecting Calf Crop: Biolechnology of Reproduction pp 255-279 Eds MI Fields, RS Sand and JV Yelich. CRC Press, Boca Raton, FL

Ii I, Slaughter RG, Ellis JA, Ji TH and Murdoch WJ (1991) Analyses of ovine corpora lutea for tumor necrosis factor IRRA and bioactivity during prostaglandin-induced luteolysis Molecular and Cellular Endocrinology $8177-80$

Kim L, Weems YS, Bridges PJ, LeaMaster BR, Ching L, Vincent DL and Weems CW (2001) Effects of indomethacin, luteinizing hormone $(\mathrm{LH})$, prostaglandin $E_{2}\left(P G E_{2}\right)$, trilostane, mifepristone, ethamoxytriphetol (MER-25) on secretion of prostaglandin E (PGE), 
prostaglandin $F_{2 a}\left(\mathrm{PGF}_{2 \alpha}\right)$ and progesterone by ovine corpora lutea of pregnancy or the oestrous cycle Prostaglandins and Other Lipid Mediators 63 189-203

Levy N, Kobayashi S, Roth Z, Wolfenson D, Miyamoto A and Meidan R (2000) Administration of prostaglandin $F_{2 \alpha}$ during the early bovine luteal phase does not alter the expression of ET-1 and of its type A receptor: a possible cause for corpus luteum refractoriness Biology of Reproduction 63 377-382

Lobel BL and Levy E (1968) Enzymatic correlates of development, secretory function and regression of follicles and corpora lutea in the bovine ovary. II. Formation, development and involution of corpora lutea Acta Endocrinologica 59 Supplement 132 35-63

Louis TM, Hafs HD and Seguin BE (1973) Progesterone, $\mathrm{LH}$, oestrus and ovulation after prostaglandin $\mathrm{F}_{2 \mathrm{x}}$ in heifers Proceedings of the Society of Experimental Biology and Medicine 143 152-155

Milvae RA (1986) Role of luteal prostaglandins in the control of bovine corpus luteum functions Journal of Animal Science 62 Supplement 272

Miyamoto A, Kobayashi S, Arata $S$, Ohtani $M$, Fukui $Y$ and Schams D (1997) Prostaglandin F $2 \alpha$ promotes the inhibitory effects of endothelin-1 on the bovine luteal function in vitro. Journal of Endocrinology 152 R7-R11

Niswender GD, Juengel IL, Silva PJ, Rollyson MK and Mclntush EW (2000) Mechanisms controlling the function and life span of the corpus luteum Physiological Reviews $801-29$

Ohtani M, Kobayashi S, Miyamoto A, Hayashi K and Fukui Y (1998) Real-time relationships between intraluteal and plasma concentrations of endothelin, oxytocin and progesterone during prostaglandin $\mathrm{F}_{2 \alpha}$-induced luteolysis in the cow Biology of Reproduction $58103-108$

Pate JL (1995) Involvement of immune cells in regulation of ovarian function Journal of Reproduction and Fertility Supplement $49365-377$

Pate JL and Keyes PL (2001) Immune cells in the corpus luteum: friends or foes? Reproduction 122 665-676

Pate JL and Townson DH (1994) Novel local regulators in luteal regression Journal of Animal Science 72 $31-42$

Penny LA, Armstrong DG, Baxter G, Hogg C, Kindahl H, Bramley T, Watson ED and Webb $R$ (1998) Expression of monocyte chemoattractant protein-1 in the bovine corpus luteum around the time of natural luteolysis Biology of Reproduction 59 1464-1469

Penny LA, Armstrong D, Bramley TA, Webb R, Collins RA and Watson ED (1999) Immune cells and cytokine production in the bovine corpus luteum throughout the oestrous cycle and after induced luteolysis /ournal of Reproduction and Fertility 115 $87-96$
Petroff MG, Petroff BK and Pate JL (1999) Expression of cytokine messenger ribonucleic acids in the bovine corpus luteum Endocrinology 1401018-1021

Petroff MG, Petroff BK and Pate IL (2001) Mechanisms of cytokine-induced death of cultured bovine luteal cells Reproduction 121 753-760

Pratt BR, Butcher RL and Inskeep EK (1977) Antiluteolytic effect of conceptus and of PGE 2 in ewes foumal of Animal Science 45 784-791

Rao CV, Estergreen VL, Carman FR, Jr and Moss GE (1979) Receptors for gonadotrophin and prostaglandin $\mathrm{F}_{2 \mathrm{u}}$ in bovine corpora lutea of early, mid-and late luteal phase Acta Endocrinologica 91 $529-537$

Redmer DA, Dai Y, Li J, Charnock-Jones DS, Smith SK, Reynolds LP and Moor RM (1996) Characterization and expression of vascular endothelial growth factor (VEGF) in the ovine corpus luteum Reproduction and Fertility 108 157-165

Redmer DA, Doraiswamy V, Bortnem BJ, Fisher K, Jablonka-Shariff A, Grazul-Bilska AT and Reynolds LP (2001) Evidence for a role of capillary pericytes in vascular growth of the developing ovine corpus luteum Biology of Reproduction 65 879-889

Ricke WA, Smith GW, McIntush EW and Smith MF (2002) Analysis of luteal tissue inhibitor of metalloproteinase $-1,-2$ and -3 during prostaglandin $\mathrm{F}_{2 \alpha}$-induced luteolysis Biology of Reproduction 66 1387-1394

Sakumoto R, Berisha B, Kawate N, Schams D and Okuda K (2000) Tumor necrosis factor- $\alpha$ and its receptor in bovine corpus luteum throughout the oestrous cycle Biology of Reproduction 62 192-199

Sawyer HR, Niswender KD, Braden TD and Niswender GD (1990) Nuclear changes in ovine luteal cells in response to $\mathrm{PGF}_{2 \alpha}$ Domestic Animal Endocrinology $7229-238$

Sayre BL, Taft R, Inskeep EK and Killefer J (2000) Increased expression of insulin-like growth factor binding protein-1 during induced regression of bovine corpora lutea Biology of Reproduction 63 21-29

Shaw DW and Britt JH (1995) Concentrations of tumor necrosis factor alpha and progesterone within the bovine corpus luteum sampled by continuousflow microdialysis during luteolysis in vivo. Biology of Reproduction $53847-854$

Silva PJ, Juengel JL, Rollilyson MK and Niswender GD (2000) Prostaglandin metabolism in the ovine corpus luteum: catabolism of prostaglandin $F_{2 \alpha}\left(P F_{20}\right)$ coincides with resistance of the corpus luteum to PGF $_{2 \alpha}$ Biology of Reproduction 63 1229-1236

Silvia WJ and Niswender GD (1984) Maintenance of the corpus luteum of early pregnancy in the ewe. III. Differences between pregnant and non-pregnant ewes in luteal responsiveness to prostaglandin $F_{20}$ Journal of Animal Science $59746-753$ 
Silvia WJ and Niswender GD (1986) Maintenance of the corpus luteum of early pregnancy in the ewe. IV. Changes in luteal sensitivity to prostaglandin $\mathrm{F}_{2 a}$ throughout early pregnancy Journal of Animal Science 63 1201-1207

Takiguchi S, Sugino N, Kashida S, Yamagata Y, Nakamura $\mathrm{Y}$ and Kato $\mathrm{H}$ (2000) Rescue of the corpus luteum and an increase in luteal superoxide dismutase expression induced by placental luteotropins in the rat: action of testosterone without conversion to estrogen Biology of Reproduction $\quad 62$ 398-403

Towle TA, Tsang PCW, Milvae RA, Newbury MK and McCracken JA (2002) Dynamic in vivo changes in tissue inhibitors of metalloproteinases 1 and 2 , and matrix metalloproteinases 2 and 9, during prostaglandin $\mathrm{F}_{2 \alpha}$-induced luteolysis in sheep Biology of Reproduction 66 1515-1521

Townson DH and Pate JL (1996) Mechanism of action of TNF- $\alpha$-stimulated prostaglandin production in cultured bovine luteal cells Prostaglandins $\mathbf{5 2}$ 361-373

Townson DH, Warren IS, Flory CM, Naftalin DM and Keyes PL (1996) Expression of monocyte chemoattractant protein-1 in the corpus luteum of the rat Biology of Reproduction 54 513-520

Townson DH, O'Connor CL and Pru IK (2002) Expression of monocyte chemoattractant protein-1 and distribution of immune cell populations in the bovine corpus luteum throughout the oestrous cycle Biology of Reproduction 66 361-366
Tsai SJ and Wiltbank MC (1998) Proslaglandin $F_{2 \alpha}$ regulates distinct physiological changes in early and mid-cycle bovine corpora lutea Biology of Reproduction $58346-352$

Tsai SJ, Juengel JL and Wiltbank MC (1997) Hormonal regulation of monocyte chemoattractant protein-1 messenger ribonucleic açid expression in corpora lutea Endocrinology $1384517-4520$

Weems YS, Lammoglia MA, Vera-Avila HR, Randel RD, King C, Sasser RG and Weems CW (1998) Effect of luteinizing hormone (LH), PGE 2, 8-EPI$P E_{1}$, trichosanthin and pregnancy specific protein $B$ (PSPB) on secretion of progesterone in vitro by corpora lutea (corpus luteum) from non-pregnant and pregnant cows Prostaglandins $5527-42$

Wiltbank JN and Casida LE (1956) Alteration of ovarian activity by hysterectomy Journal of Animal Science $15134-140$

Wiltbank MC, Wiepz GJ, Knickerbocker J, Belfiore CJ and Niswender GD (1992) Proteins secreted from the early ovine conceptus block the action of prostaglandin $\mathrm{F}_{2 \alpha}$ on large luteal cells Biology of Reproduction $46475-482$

Wiltbank MC, Shiao TF, Bergfelt DR and Ginther OJ (1995) Prostaglandin $F_{2 \alpha}$ receptors in the early bovine corpus luteum Biology of Reproduction 52 74-78

Wright MF, Sayre B, Inskeep EK and Flores JA (2001) Prostaglandin $F_{2 \alpha}$ regulation of the bovine corpus luteum endothelin system during the early and midluteal phase Biology of Reproduction 65 1710-1717 